\title{
ASSESSMENT OF CUSTOMER SATISFACTION sciendo AS AN ELEMENT DECIDING ABOUT ENTERPRISE'S COMPETITIVENESS
}

doi:10.2478/mape-2018-0083

Date of submission of the article to the Editor: 03/2018

Date of acceptance of the article by the Editor: $07 / 2018$

\author{
MAPE 2018, volume 1, issue 1, pp. 657-664
}

PhD., Eng. Manuela Ingaldi

Czestochowa University of Technology, Poland

Doc. Ing. Martin Kotus PhD.

Slovak University of Agriculture in Nitra, Slovak Republic

\begin{abstract}
Enterprises which want to ensure a secure and stable market position must constantly look for ways to convince customers (current and potential) that their goods and services are competitive and represent a sufficiently high level of quality, consistent with the their needs. Service enterprises use specific methods and tools to analyze the quality of their services and to be sure that these services are competitive on the market. One of the important elements of such an analysis is the assessment of customer satisfaction. This research should be treated as a key stage in the customer satisfaction management system. Without knowing the customers' expectations, the enterprise is unable to determine what to improve and correct. In this case, the Customer Satisfaction Index (CSI), which not only indicates what to improve, but also shows the level of customer satisfaction, should be used. The purpose of the paper is to assess customer satisfaction in a service point of a known producer of men's clothes. The CSI index and a specially developed survey were used for the research. The questionnaire was filled in by the customers of the research service point after the service delivery. According to the obtained results, individual determinants should be maintained and monitored by the enterprise. The research also identified areas for improvement, i.e. product quality, design and ways of payment. However, the overall CSI score is good, which means that despite few problems with customers' satisfaction, they are satisfied with the research service point.
\end{abstract}

Keywords: service quality; customer's opinion, CSI; quality management

\section{INTRODUCTION}

Every enterprise looks for solutions, how to convince customers to its products, and, thus, how to ensure a secure and stable market position. It should be kept in mind that this can be achieved when all expectations of customers are met, and the result is that the customer is satisfied.

Meeting customers' expectations is determined by their attitude and preferences. Therefore, the measurement of customer satisfaction with the offered goods and services is designed to examine what kind of expectations customers have. Assessment of customer satisfaction also allows to determine what features should be included in products and services offered by the enterprise - in this way customer satisfaction attributes are determined (Pawłowska and Struchalska-Rudziewicz, 2005; Nieżurawski and Śmiatacz, 2012). Customer satisfaction, which is a kind of reflection of the quality of offered goods and services, is also a source of customer loyalty towards the enterprise (Dulska et al., 2017; Futas et al., 2017; Jelonek et al., 2017). A satisfied customer is often a loyal customer who likes to use a proven brand.

To assess customer satisfaction, various types of quantitative and qualitative methods, various types of analyzes and indicators are very often used. One of such indicators is the Customer Satisfaction Index (CSI). 
The purpose of the paper is to assess customer satisfaction in a service point of a known producer of men's clothes on the basis of CSI. To conduct the research, it was necessary to construct an appropriate survey (questionnaire), which included an assessment of the importance and satisfaction of twenty determinants that could have an impact on the satisfaction of customers of the research service point. The research allowed to identify those determinants that need improvement. The overall level of customer satisfaction (CSI index) was also assessed.

The research was conducted in a chosen service point of a known producer of men's clothes. The research service point sells products from the producer, but also offers services related to the selection and processing of clothes according to customers' requirements.

\section{METHODOLOGY OF RESEARCH}

The CSI index is constructed on the basis of a model of building customer satisfaction based on connections and dependencies between three groups of factors: perceived quality, expected quality and perceived price-to-quality ratio. This approach allows measuring and analyzing the level of customer satisfaction in terms of every feature relevant to customer satisfaction as well as total satisfaction with the purchase and consumption of a product/service (Sygut et al., 2016; Yazdanpanah and Feyzabad, 2017).

The most available and understandable methodology for calculating the CSI index was given by Hall. According to this author, calculating indicators should include in short: recognition of customer satisfaction criteria (exploratory phase, carried out in the form of group or individual interview, surveys), determination of their hierarchy, e.g. by assigning by each respondent with value for example from 1 to 5 (where, for example, 1 means very little importance and 5 stands for very large), the respondents' assessment of each criterion in relation to the examined organization on the adopted scale (e.g. from 1 to 5 , where 1 means insufficient grade and 5 very good), and finally, calculation of the CSI index, according to the formula (Hall, 2013):

$$
C S I=\sum_{j=1}^{n}\left(\frac{\sum_{i=1}^{c}\left(w_{i j} \times o_{i j}\right)}{\sum_{i=1}^{c}\left(w_{i j} \times m_{i}\right)}\right) / \mathrm{n}
$$

where:

$c$ - number or satisfaction criteria;

$n$-number of interviewed people;

$w$ - importance of the satisfaction criterion (wij is the importance of the $\mathrm{i}$-th criterion for $\mathrm{j}$-th respondent's);

$o$ - assessment of the satisfaction criterion (wij is the assessment of the $\mathrm{i}$-th criterion for $\mathrm{j}$-th respondent's);

$m$ - maximum assessment of the satisfaction criterion ( $\mathrm{mi}$ is theoretically the highest assessment of $\mathrm{i}$-th satisfaction criterion).

Interpretation of the CSI index was presented in Table 1.

Table 1

Criteria for assessment of the CSI index

\begin{tabular}{|l|l|}
\hline \multicolumn{1}{|c|}{ Value of CSI [\%] } & \multicolumn{1}{c|}{ Assessment } \\
\hline $0-40$ & Very bad - an extremely dissatisfied customer. \\
\hline $40-60$ & Bad - a dissatisfied customer. \\
\hline $60-75$ & Average - there are some problems in terms of customer satisfaction. \\
\hline $75-90$ & Good - there are few problems with customer satisfaction. \\
\hline $90-100$ & Very good - an extremely satisfied customer. \\
\hline
\end{tabular}

Source: (Woźniak and Zimon, 2016). 
Data for the research are collected in the form of a survey. Respondents indicate both the importance of a given criterion and its assessment (his satisfaction level). An example form of the questionnaire of such a survey was presented in Table 2 . This form of questions facilitates both data collection and filling in the questionnaire itself.

\section{Table 2}

A fragment of the table that allows to determine the importance of the identified satisfaction criteria according to the CSI method

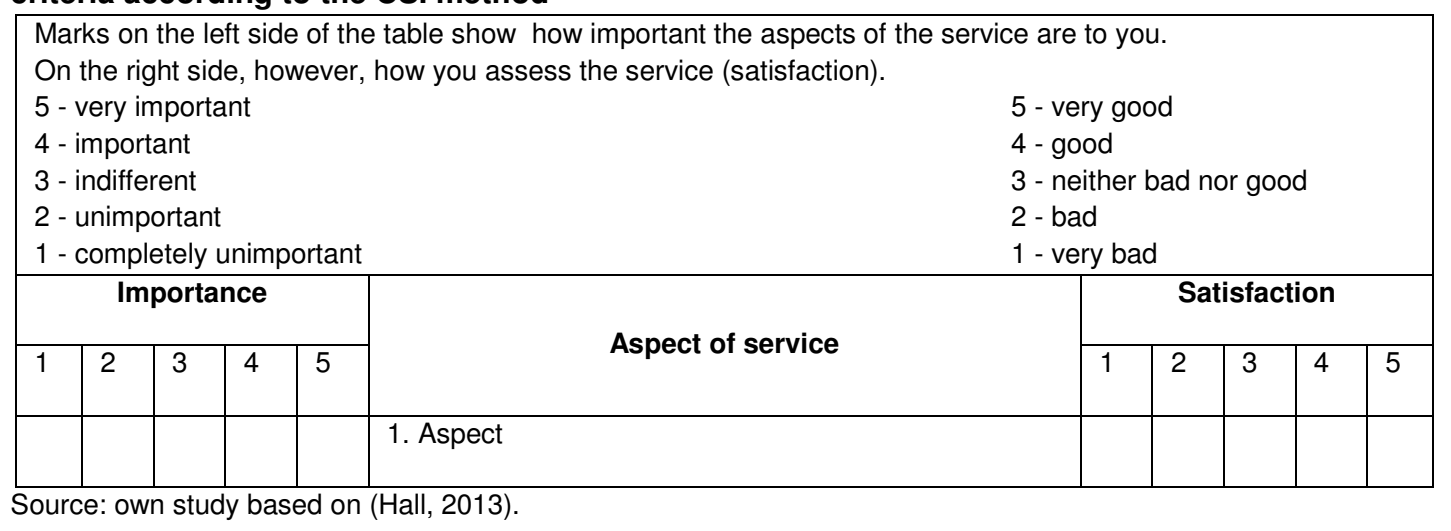

The customer satisfaction surveys do not provide full knowledge about his purchasing behavior. The customer can only describe how content he is with the previous purchases or contact with the seller, but does not make a declaration of loyalty. What is more, it may be interesting to note that the majority of research about correlation between customer satisfaction and loyalty indicate that high satisfaction estimated at over $90 \%$ often corresponds to loyalty that reaches only 50\% (Badania satysfakcji i lojalności klientów, 2017; Stodulny, 2006; Shin, 2014).

The CSI method allows to create a matrix of satisfaction factors (a map of satisfaction factors), which is a coordinate system with axes expressing: the importance of criteria and respondents' satisfaction, where after the completion of the research, there are placed points of individual, distinguished satisfaction criteria. This matrix allows for quick visual identification of criteria requiring immediate improvement, i.e. high importance for customer but low assessed (neglected factors), not important and low assessed (irrelevant factors), not important but highly assessed (contributed factors) and the strongest sides of a given organization, i.e. high importance and highly assessed criteria (Hall, 2013). The CSI matrix was shown in Figure 1. It should be remembered that customer's good and satisfaction is the basis of the enterprise's existence. It is necessary to acknowledge his needs and expectations. The customer's satisfaction, but also its types are influenced by many factors, including his expectations, previous experience, trust in the service or enterprise, image of the service on the market, perception of the service, its characteristics, requirements for the service, but also individual features (personality of the customer) that affect his behavior, decisions and choice. Assessment of customers' satisfaction allows to indicate the strengths of a given service, but also allows to indicate where the improvements are required (Woźniak and Zimon, 2016; Snarski, 2012; Kardas et al., 2017). 


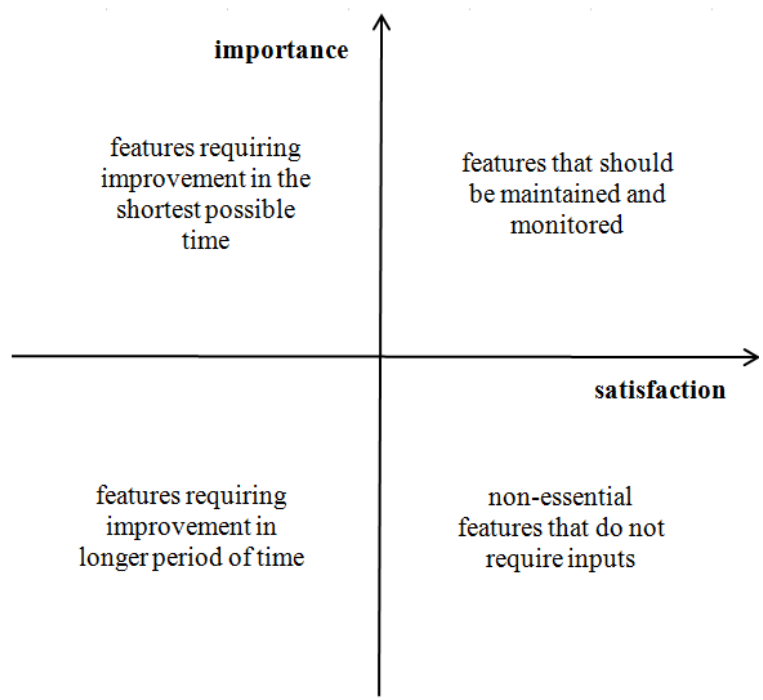

Fig. 1. CSI matrix

Source: based on (Badania satysfakcji i lojalności klientów, 2017).

\section{RESULTS}

The questionnaire was filled in by 57 customers of the research service point after the service delivery. Due to the fact that some of the forms were not filled in completely, only 50 questionnaires were analyzed. In Table 3 a summary of results was presented. During the research, the questionnaire created by Pietraga (2018) was partly used.

According to the customers of the research service point, the most important determinant were the following: product quality and ways of payment. The specificity of the research object should be emphasized. It is a service point that helps to select, sells and processes (to size) suits. Customers of such points are very specific, most often they are men with quite a high income who work in big enterprises, often as managers or representatives, which requires from them an appropriate style of clothing. It is easier for them to use a credit card.

The customers indicated also the least important determinants, i.e., promotional campaigns and behavior of employees. The first determinant is again dictated by the specificity of customers. Those who are better paid often want to make purchases quickly, are willing to pay any price, rarely pay attention to various types of promotional campaigns. What is surprising is the low importance of behavior of employees. While it is important for most customers whether the seller is well-mannered and polite, especially rich customers have high requirements concerning the behaviour of shop assistants because they pay more, and, therefore, feel entitled to expect more.

The customers stated that the most satisfactory determinant in the case of the research object was availability of products. They did not have to wait for the delivery of products, they immediately found all the things they needed.

Design was assessed the worst in terms of satisfaction. Customers follow on the Internet or in the press what the trends appear in the global fashion, which may result in this determinant being assessed so low. 
Table 3

Detailed analysis of customer satisfaction determinants

\begin{tabular}{|c|c|c|c|c|c|c|c|c|c|c|c|c|}
\hline \multirow{3}{*}{ 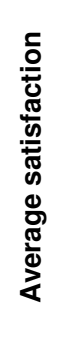 } & \multicolumn{5}{|c|}{ Satisfaction } & \multirow{3}{*}{$\begin{array}{l}\text { Satisfaction's } \\
\text { determinants }\end{array}$} & \multicolumn{5}{|c|}{ Importance } & \multirow{3}{*}{ 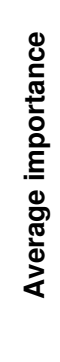 } \\
\hline & $\begin{array}{l}\text { 이 } \\
\text { ᄋ } \\
\frac{7}{0}\end{array}$ & : & 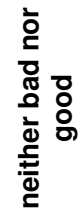 & $\begin{array}{l}\text { \% } \\
\text { ه్ }\end{array}$ & 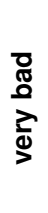 & & 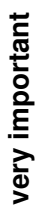 & 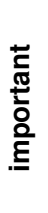 & 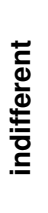 & 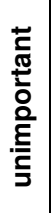 & 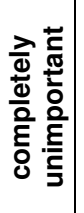 & \\
\hline & 5 & 4 & 3 & 2 & 1 & & 5 & 4 & 3 & 2 & 1 & \\
\hline 3.68 & 15 & 16 & 10 & 6 & 3 & 1. Product price & 20 & 18 & 6 & 3 & 3 & 3.98 \\
\hline 3.76 & 18 & 15 & 8 & 5 & 4 & 2. Product quality & 50 & 0 & 0 & 0 & 0 & 5 \\
\hline 4.18 & 25 & 16 & 4 & 3 & 2 & 3. Brand & 35 & 10 & 3 & 1 & 1 & 4.54 \\
\hline 3.5 & 14 & 16 & 8 & 5 & 7 & 4. Assortment & 8 & 19 & 15 & 4 & 4 & 3.46 \\
\hline 3.18 & 5 & 21 & 9 & 8 & 7 & 5. Design & 42 & 4 & 2 & 2 & 0 & 4.72 \\
\hline 3.9 & 17 & 15 & 15 & 2 & 1 & 6. Opening hours & 20 & 15 & 6 & 7 & 2 & 3.88 \\
\hline 4.22 & 24 & 17 & 6 & 2 & 1 & 7. Comfort of shopping & 34 & 11 & 3 & 1 & 1 & 4.52 \\
\hline 3.84 & 18 & 15 & 11 & 3 & 3 & 8. Ways of payment & 45 & 5 & 0 & 0 & 0 & 4.9 \\
\hline 4.54 & 34 & 11 & 3 & 2 & 0 & 9. Promotional campaigns & 6 & 10 & 25 & 6 & 3 & 3.2 \\
\hline 3.82 & 18 & 15 & 11 & 2 & 4 & 10. Post-season discounts & 13 & 14 & 10 & 4 & 9 & 3.36 \\
\hline 3.72 & 17 & 13 & 12 & 5 & 3 & 11. Empathy & 10 & 16 & 12 & 9 & 3 & 3.42 \\
\hline 3.92 & 20 & 17 & 5 & 5 & 3 & 12. Complains & 25 & 20 & 3 & 2 & 0 & 4.36 \\
\hline 4.28 & 28 & 12 & 6 & 4 & 0 & 13. Customer service & 18 & 16 & 10 & 2 & 4 & 3.84 \\
\hline 3.88 & 20 & 16 & 6 & 4 & 4 & 14. Advertisement & 30 & 18 & 0 & 2 & 0 & 4.52 \\
\hline 4.46 & 27 & 21 & 0 & 2 & 0 & 15. Speed of order fulfillment & 24 & 18 & 4 & 2 & 2 & 4.2 \\
\hline 3.78 & 15 & 18 & 10 & 5 & 2 & 16. Behavior of employees & 6 & 24 & 5 & 10 & 5 & 3.32 \\
\hline 3.74 & 17 & 15 & 10 & 4 & 4 & 17. Transparency of the offer & 18 & 16 & 8 & 6 & 2 & 3.84 \\
\hline 5 & 50 & 0 & 0 & 0 & 0 & 18. Availability of products & 20 & 18 & 7 & 5 & 0 & 4.06 \\
\hline 3.56 & 15 & 14 & 10 & 6 & 5 & 19. Additional services & 20 & 15 & 7 & 5 & 3 & 3.88 \\
\hline 3.78 & 20 & 13 & 6 & 8 & 3 & 20. Loyalty rewards & 18 & 19 & 3 & 4 & 6 & 3.78 \\
\hline
\end{tabular}

\section{DISCUSSION}

Results included in Table 3 were presented in graphical way with the use of the CSI matrix (Figure 2). In the figure there are marked points corresponding to customer satisfaction (X axis) and the importance of determinants ( $\mathrm{Y}$ axis).

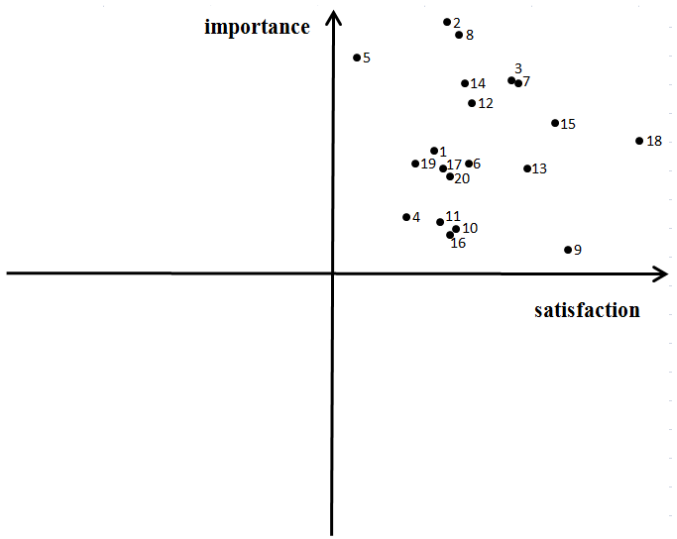

Fig. 2. CSI matrix with assessments of the research determinants

Analyzing Figure 2 it can be seen that all the points corresponding to individual determinants are placed in the first quarter of the Cartesian system. These features, according to CSI matrix presented in Figure 1, should be maintained and monitored. 
Such a result proves a high level of customer satisfaction with important determinants affecting the overall satisfaction with the services offered by the research service point. The enterprise should try to maintain the results at present level or, if it is possible, try to increase them constantly. First of all, the enterprise should not allow a situation in which particular points change their location to other quarters, because it will be a sign of deterioration of customers' opinions about the research service characteristics.

It should be emphasized, however, that the points presented in Figure 2 are scattered, which means a large diversity in terms of customer satisfaction. Therefore, these results were further analyzed. In Figure 3 a comparison of importance and satisfaction for individual determinants was presented. While in Figure 4 difference between satisfaction and importance was shown.

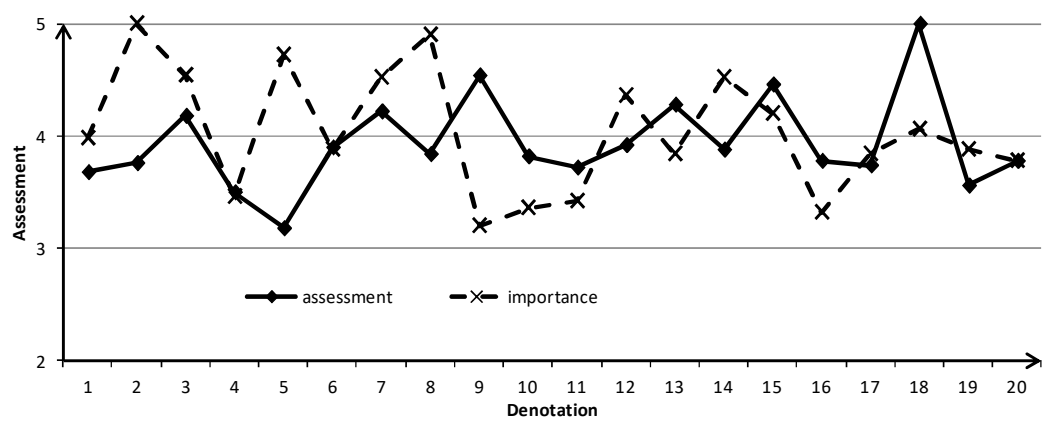

Fig. 3. Comparison of determinants' importance and their satisfaction

Figure 3 showed a large diversity of assessments of both importance and satisfaction. Analyzing Figure 4, it can be concluded that, according to the customers' opinion, three determinants require improvement, i.e. product quality, design and ways of payment. For these three determinants, the difference between satisfaction and importance was negative and was below -1 .

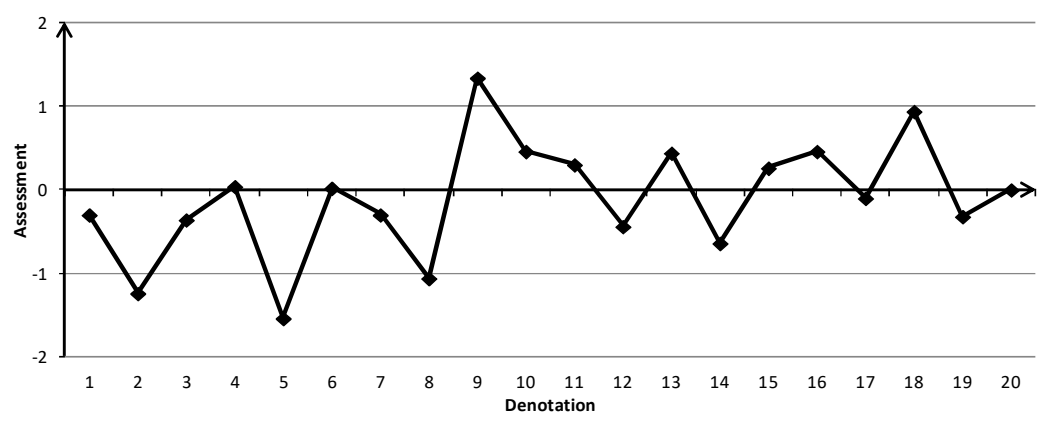

Fig. 4. Difference between satisfaction and importance

In the next steep the CSI index was calculated. This index was:

$$
\text { CSI }=77.8 \%
$$

Comparing the result to the data shown in Table 1, it can be concluded that the level of customer satisfaction according to CSI index is good, which confirms previous results. It can therefore be assumed that a large part of customers will again visit the researched service point or another point of the same enterprise.

As it as shown earlier, there are there are few problems with customer satisfaction. These are the determinants for which the difference between satisfaction and importance was negative. 


\section{CONCLUSION}

Enterprises looks for different solutions to obtain as many customers as possible, the largest share in the market, and, thus, become competitive on the market. To make this possible, customers of such enterprises should be satisfied with their products and services.

In the paper assessment of customer satisfaction in a service point of a known producer of men's clothes was conducted. Customer Satisfaction Index (CSI) was used for this assessment. To conduct the research, it was necessary to construct an appropriate survey (questionnaire), which included an assessment of the importance and satisfaction of twenty determinants that could have an impact on the satisfaction of customers of the research service point.

According to respondents (customers of the research service point) CSI index was good. What was confirmed also by CSI matrix, according to which all the determinants indicated in the survey are in the first quarter of the Cartesian system. It means that these determinants should be maintained and monitored.

Three determinants need an improvement, i.e. product quality, design and ways of payment. For these three determinants, the difference between satisfaction and importance was negative and was below -1 .

Customers expect that the suits and accessories they buy will be of the highest quality and with the modern design. Therefore, the enterprise should introduce new products to its offer faster. The research service point offers possibility to pay with a credit card, so the need to improve this determinant is surprising. Perhaps it was related to periodic problems with the payment terminal, which unfortunately cannot be avoided because it does not depend on the research object.

It should be emphasis that customers of such points are very specific, most often they are men with quite a high income, working in big enterprises, often as managers, representatives. In the case of such people it is more difficult to meet their expectations and requirements. Therefore, the results achieved by the research enterprise should be treated positively.

\section{REFERENCES}

Badania satysfakcji i lojalności klientów. [online] Available at: http://research.inse.pl/oferta/obszarybadawcze/badaniasatysfakcji, [Accessed 10 May 2017].

Dulska, A., Studnicki, S. and Szajnar, J. (2017). Reinforcing cast iron with composite insert. Archives Of Metallurgy And Materials, 62(1): pp. 355-357.

Futas, P., Pribulova, A., Fedorko, G. and Molnar, V. (2017). Influence of Steel Scrap in the Charge on the Properties of Gray Cast Iron. ISIJ International, 57(2), pp. 374-379.

Hall, H. (2016). Zastosowanie metod NPS i CSI w badaniach poziomu satysfakcji i lojalności studentów. Modern Management Review, MMR, XVIII, 20 (1), pp. 51-61.

Ingaldi, M. and Ulewicz, R. (2018). Evaluation of Quality of the e-Commerce Service. International Journal of Ambient Computing and Intelligence, 9(2), pp.55-66.

Jelonek, D., Dunay, A. and Illes, B,C. (2017). Academic e-learning management with e-learning scorecard. Polish Journal Of Management Studies, 16(2) pp. 122-132.

Kardas, E., Brozova, S., Pustejovska, P. and Jursova, S. (2017). The evaluation of efficiency of the use of machine working time in the industrial company - case study. Management Systems In Production Engineering, vol. 25, iss. 4, pp. 241-245.

Nieżurawski, L. and Śmiatacz, K. (2012) System zarządzania satysfakcją klienta na przykładzie rynku telefonii komórkowej. Studia i Materiały. Miscellanea Oeconomicae, 16(2), pp. 153-162.

Pawłowska, B. and Struchalska-Rudziewicz, A. (2005). Badanie satysfakcji klienta w systemie zarządzania jakością. [online] Available at: http://statkiewicz.weii.tu.koszalin.pl/zpi/zj/pawlowska.pdf [Accessed 10 May 2017].

Pietraga, D. (2018). Badanie satysfakcji klienta jako element zarządzania jakością w przedsiębiorstwie. Diploma thesis. Częstochowa: Politechnika Częstochowska, Wydział Zarządzania.

Shin, D.H. (2014). Measuring the quality of smartphones: development of a customer satisfaction index for smart services. International Journal Of Mobile Communications, 12(4), pp. 311-327.

Snarski, P. (2012). Metody pomiaru satysfakcji klientów bankowych wykorzystywanych do analizy konkurencyjności banków. Economy and Management, 2, pp. 92-108.

Stodulny, P. (2006). Analiza satysfakcji i lojalności klientów bankowych. Warszawa: CeDeWu. 
Sygut, P., Klimecka-Tatar, D. and Borkowski, S. (2016). Theoretical analysis of the influence of longitudinal stress changes on band dimensions during continuous rolling process. Archives Of Metallurgy And Materials, 61(1), pp. 183-188.

Woźniak, J. and Zimon, D. (2016). Zastosowanie metody CSI do badania satysfakcji konsumentów na przykładzie wybranej sieci handlowej. Modern Management Review, MMR, XXI, 23(3), pp. 219228.

Yazdanpanah, M. and Feyzabad, F.R. (2017). Investigating Iranian Farmers' Satisfaction With Agricultural Extension Programs Using the American Customer Satisfaction Index. Journal Of Agricultural \& Food Information, 18(2), pp. 123-135. 